ANL/NT/CP- 97702

\title{
Development of a Ceramic Waste Form For High-Level Waste Disposal
}

By:

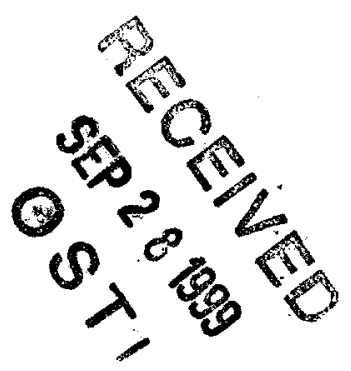

D.W. Esh, K. M. Goff, K. T. Hirsche, T. J. Battisti, M. F. Simpson, S. G. Johnson, and $\mathrm{K}$. J. Bateman

\author{
Nuclear Technology Division \\ Engineering Division \\ Argonne National Laboratory-West \\ P. O. Box 2528 \\ Idaho Falls, ID 83403-2528

\begin{abstract}
The submitted manuscript has been created. by the University of Chicago as Operator of Argonne National Laboratory ("Argonne") under Contract No. W-31-109-ENG-38 with the U.S. Department of Energy. The U.S. Government retains for itself, and others act-

ing on its behalf, a paid-up, nonexclusive,

irrevocable worldwide license in said article

to reproduce, prepare derivative works, dis-

tribute copies to the public, and perform pub-

licly and display publicly, by or on behalf of

the Government.
\end{abstract}

To be presented

at

Materials Research Society

Fall Meeting

Boston, Mass.

November 29- December 4, 1998

* Work supported by the U. S. Department Energy, Office of Nuclear Energy, Science and Technology, and the Office of Environmentat Management, under contract W-31-109-Eng-38. 


\section{DISCLAIMER}

This report was prepared as an account of work sponsored by an agency of the United States Government. Neither the United States Government nor any agency thereof, nor any of their employees, make any warranty, express or implied, or assumes any legal liability or responsibility for the accuracy, completeness, or usefulness of any information, apparatus, product, or process disclosed, or represents that its use would not infringe privately owned rights. Reference herein to any specific commercial product, process, or service by trade name, trademark, manufacturer, or otherwise does not necessarily constitute or imply its endorsement, recommendation, or favoring by the United States Government or any agency thereof. The views and opinions of authors expressed herein do not necessarily state or reflect those of the United States Government or any agency thereof. 


\section{DISCLAIMER}

Portions of this document may be illegible in electronic image products. Images are produced from the best available original document. 


\section{DEVELOPMENT OF A CERAMIC WASTE FORM FOR HIGH-LEVEL WASTE DISPOSAL}

D.W. Esh, K.M. Goff, K.T. Hirsche, T.J.Battisti, M.F. Simpson, S.G. Johnson, and K.J. Bateman Argonne National Laboratory-West, Idaho Falls, ID 83403

\section{ABSTRACT}

A ceramic waste form is being developed by Argonne National Laboratory ${ }^{*}$ (ANL) as part of the demonstration of the electrometallurgical treatment of spent nuclear fuel.[1] The halide, alkaline earth, alkali, transuranic, and rare earth fission products are stabilized in zeolite which is combined with glass and processed in a hot isostatic press (HIP) to form a ceramic composite. The mineral sodalite is formed in the HIP from the zeolite precursor. The process, from starting materials to final product, is relatively simple. An overview of the processing operations is given. The metrics that have been developed to measure the success or completion of processing operations are developed and discussed. The impact of variability in processing metrics on the durability of the final product is presented.

\section{INTRODUCTION}

Within the Department of Energy, there exists almost 60 metric tons heavy metal (MTHM) of sodium-bonded spent nuclear fuel. Sodium was used to provide a thermal bond between the fuel matrix and cladding. Because of the presence of the highly reactive sodium metal, the fuel is generally believed to not be suitable for direct disposal in a geologic repository.[2] Argonne National Laboratory is demonstrating a electrometallurgical treatment process to prepare sodium-bonded fuels for eventual disposal.

Spent fuel elements are electrochemically dissolved in a molten salt medium.[3] The molten salt medium is a mixture of $\mathrm{LiCl}-\mathrm{KCl}$ eutectic and actinide chlorides, such as $\mathrm{UCl}_{3}$. During the electrochemical dissolution, uranium is deposited on a steel cathode. The uranium is separated from the bulk of the fission products and transuranics. Most of the transuranics and fission products (alkali, alkaline earth, rare earth, and halides) accumulate in the salt. The highly reactive sodium is converted to benign $\mathrm{NaCl}$. The salt is eventually processed to produce the ceramic waste form.

The precursor materials used to produce the ceramic waste form are dried zeolite A, salt containing fission products and transuranics, and glass frit. Zeolites are crystalline aluminosilicates of the group I (alkali) and group II (alkaline earth) elements. The composition of zeolite $\mathrm{A}$ is given by $\mathrm{Na}_{12}\left[\left(\mathrm{AlO}_{2}\right)_{12}\left(\mathrm{SiO}_{2}\right)_{12}\right]$. Tetrahedra of $\mathrm{AlO}_{4}$ and $\mathrm{SiO}_{4}$ form a framework into which molecules can be occluded. In addition, the sodium ions are subject to ion exchange. When the zeolite is processed at elevated temperatures, it converts to the mineral sodalite, $\mathrm{Na}_{6}\left[\left(\mathrm{AlO}_{2}\right)_{6}\left(\mathrm{SiO}_{2}\right)_{6}\right] \bullet 2 \mathrm{NaCl}$. While zeolite $\mathrm{A}$ consists of a large (11.4 angstroms diameter) $\alpha$ cage and a smaller (6.6 angstroms diameter) $\beta$ cage, sodalite has only the $\beta$ cage.

* The submitted manuscript has been authored by a contractor of the U.S. Government under Contract No. W-31-109-ENG-38. Accordingly, the U.S. Government retains a nonexclusive, royalty-free license to publish of reproduce the published form of this contribution, or allow others to do so, for U.S. Government purposes.

\section{PROCESSING OPERATIONS}

Development of the ceramic waste form on the laboratory-scale has occurred in the Chemical Technology Division of ANL in Mlinois. The current work at ANL-West is 


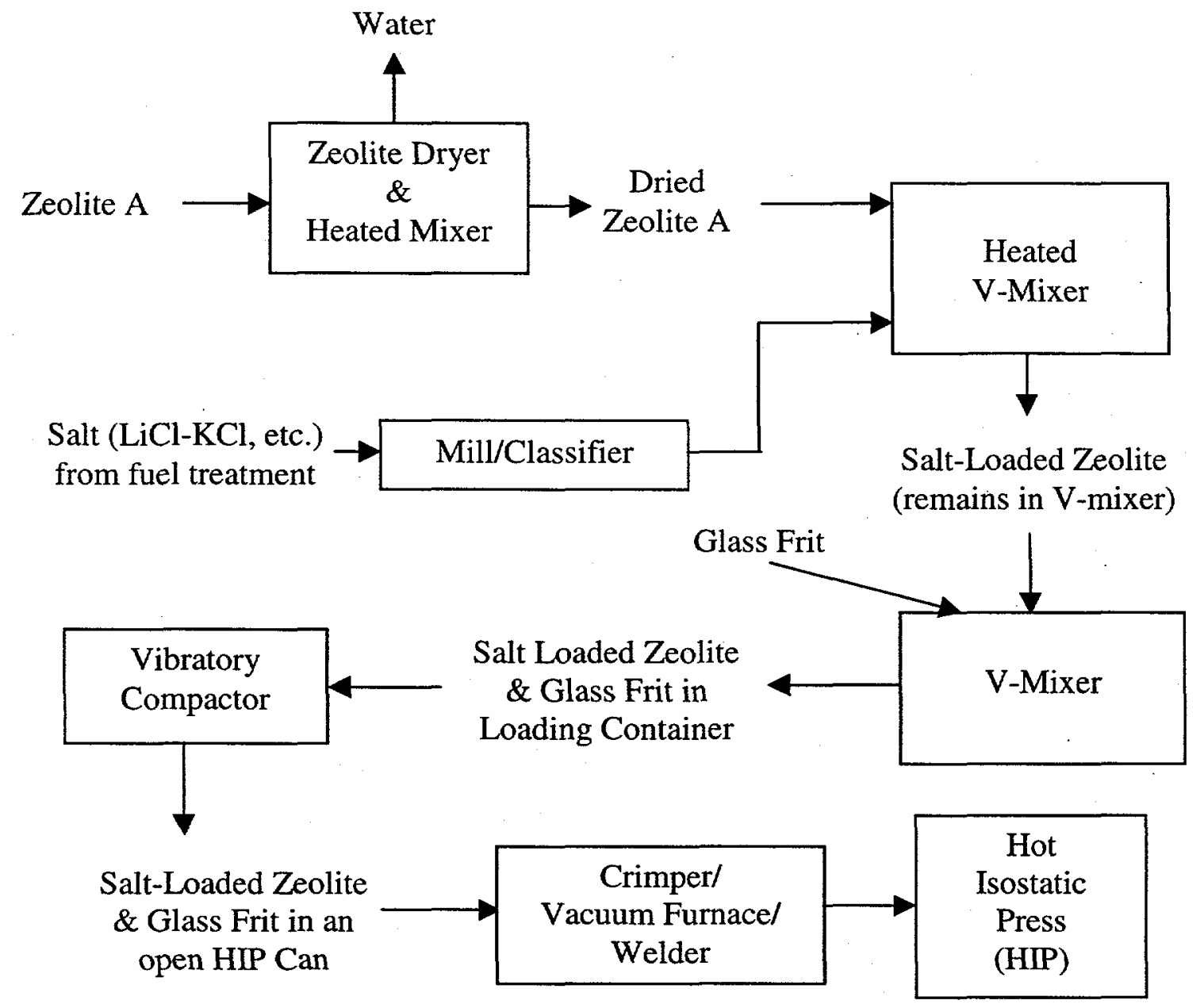

Figure 1 Flowsheet of the Ceramic Waste Form Production Process

focused on producing large-scale, and eventually production scale, ceramic waste forms. The processing operations required to produce the ceramic waste form are relatively simple. Figure 1 is a flowsheet of the ceramic waste form production process.

The first piece of equipment in the flowsheet is the zeolite dryer. Zeolite A naturally occludes more than $20 \mathrm{wt}$.\% water. The water is removed before the zeolite is contacted with the salt in an attempt to facilitate the occlusion of salt into zeolite. Different systems have been utilized to dry zeolite $\mathrm{A}$, with batch sizes ranging from 5 to $34 \mathrm{~kg}$. Common to all drying systems is heating the zeolite to $550^{\circ} \mathrm{C}$ at $2^{\circ} \mathrm{C} / \mathrm{min}$ under a vacuum. The minimum drying cycle time has been determined to be 12 hours.

Powdered zeolite with an average particle size of less than $10 \mu \mathrm{m}$ was used in initial development work. However, due to perceived handling difficulties and to achieve better packing in the HIP can before processing, a standard particle size distribution having a mean in the range of 75 to $170 \mu \mathrm{m}$ was defined. To increase the efficiency of mixing, the salt from the electrorefiner is milled to a similar mean particle size using a mill/classifier from Prater Industries, Inc. A cyclone separator is used to collect the salt after milling. Experimentation has determined that the mill and classifier should be set at speeds of 1500 and $500 \mathrm{rpm}$, respectively, to deliver an acceptable mean particle size.

The salt from the milling and the dried zeolite are combined in a heated V-mixer. Salt is occluded into the zeolite by heating to more than $500^{\circ} \mathrm{C}$ while mixing at $15 \mathrm{rpm}$. The capacity of the v-mixer is more than $50 \mathrm{~kg}$ of powder, but it is typically operated with $4.1 \mathrm{~kg}$ of salt and 31 
$\mathrm{kg}$ of dried zeolite. The materials are rotated in the $\mathrm{v}$-mixer and then heat is applied to increase the temperature to $500^{\circ} \mathrm{C}$. This state is maintained for up to 15 hours in order to occlude the molten salt into the zeolite structure. After cooling, typically $25 \mathrm{wt} \%$ glass frit is added to the salt-loaded zeolite and the materials are cold-mixed.

The blended materials are loaded into cans that are eventually processed in a hot isostatic press (HIP). A vibratory compactor is utilized to increase the packing density of the mixture in the HIP can to approximately 50 percent of theoretical. Next the can is heated to $500^{\circ} \mathrm{C}$ and evacuated. The tube used to fill the can is crimped and welded, providing a sealed, evacuated. can for processing in the HIP. The HIP used for the demonstration project was manufactured by $\mathrm{ABB}$ Autoclave, Inc. The operating gas is argon, and its chamber is $15.2 \mathrm{~cm}$ in diameter and $30.5 \mathrm{~cm}$ in height. The HIP is capable of reaching a maximum temperature of $1450^{\circ} \mathrm{C}$ and a maximum pressure of $207 \mathrm{MPa}$. However, a typical processing cycle has a maximum temperature of $850^{\circ} \mathrm{C}$ and a maximum pressure of $100 \mathrm{MPa}$, which are maintained for 1.0 hours.

\section{OPERATION METRICS}

The success or completeness of each operation is evaluated in terms of operation metrics. The operation metrics are believed to be a suitable indicator of the success of the operations. Table 1 is a compilation of the current metrics for each operation of the ceramic waste form development process. All assessments of the impact on the final product are preliminary. A more involved study using the statistical design of experiments is being completed to further evaluate the impact of operational metric variation on the final product. Only select operation metrics are discussed below.

Table 1. Current Operation Metrics for the Ceramic Waste Form Development Process

\begin{tabular}{|c|c|c|c|}
\hline Operation & Objective & Metric & $\begin{array}{l}\text { Assessment of } \\
\text { Impact on } \\
\text { Final Product }\end{array}$ \\
\hline Zeolite drying & $\begin{array}{c}\text { reduce } \mathrm{H}_{2} \mathrm{O} \text { to less than } \\
0.3 \text { wt. } \%\end{array}$ & moisture content & preliminary \\
\hline Salt grinding & $\begin{array}{l}\text { maintain mean particle } \\
\text { size of the salt similar to } \\
\text { the zeolite }\end{array}$ & mean particle size, $\mathrm{PSD}$ & $\mathrm{no}^{*}$ \\
\hline Heated v-mixing & occlude salt in zeolite & free chloride & yes \\
\hline Cold v-mixing & $\begin{array}{l}\text { mix salt-loaded zeolite } \\
\text { with glass }\end{array}$ & none & no \\
\hline Vibratory compacting & $\begin{array}{l}\text { increase packing density } \\
\text { of materials in HIP can }\end{array}$ & mass added to HIP can & yes \\
\hline Can bake-out & remove residual moisture & $\begin{array}{l}\text { change in vacuum pump } \\
\text { pressure }\end{array}$ & yes \\
\hline $\begin{array}{l}\text { Crimping/ } \\
\text { Welding }\end{array}$ & seal HIP can & leak test & no \\
\hline HIP processing & $\begin{array}{c}\text { convert zeolite to sodalite } \\
\text { solidify and densify } \\
\text { materials } \\
\end{array}$ & $\begin{array}{c}\text { XRD } \\
\text { volume change }\end{array}$ & yes \\
\hline $\begin{array}{ll}* & \text { assessment on } \\
* * & \text { all assessment } \\
* * * & \text { we are workin }\end{array}$ & $\begin{array}{l}\text { ade of impact on next pro } \\
\text { impact on final product ar } \\
\text { assess the degree of mixin }\end{array}$ & $\begin{array}{l}\text { sing operation } \\
\text { reliminary }\end{array}$ & \\
\hline
\end{tabular}


The zeolite drying operation is utilized to remove the more than $20 \mathrm{wt} \%$ water that the zeolite A occludes naturally. To date, over 50 experiments have been completed to dry zeolite A in quantities ranging from 3.8 to $36.4 \mathrm{~kg}$. The common temperature for a zeolite drying experiment is $550^{\circ} \mathrm{C}$, although experiments have been completed as high as $650^{\circ} \mathrm{C}$. The operation metric for zeolite drying is the final moisture content of the zeolite. A Karl Fischer technique as well as an infrared (IR) device are used to evaluate moisture content of the dried zeolite.[4] Moisture content has been estimated for well over 100 samples, with a mean value of 0.30 and a range of 0.04 to $2.1 \mathrm{wt} . \%$.

Salt grinding is used to produce salt particles with a similar mean particle size as the reference dried zeolite to achieve adequate mixing. A detailed study has been completed to evaluate the impact of mill and classifier speed variation on the mean particle size of the product. Over 30 experiments have been completed to determine the operating parameters of the grinder. Salt has been ground to a mean particle size of less than $10 \mu \mathrm{m}$ and greater than $200 \mu \mathrm{m}$. Excellent reproducibility has been demonstrated for experiments with similar operating conditions. The most sensitivity of mean particle size to the operating parameters was observed when the mill speed was varied while the classifier speed was low $(500 \mathrm{rpm})$. A mean particle size of approximately $200 \mu \mathrm{m}$ has been used for all recent contacting experiments.

Heated v-mixing is the operation utilized to occlude salt into the zeolite cages. To produce a sodalite waste form, approximately $11.7 \mathrm{wt} . \%$ salt is added to the dried zeolite. The exact amount of salt added to the zeolite is dependent on the composition of the salt. The target salt loading is $3.8 \mathrm{Cl}$ /unit cell compared to the theoretical value for sodalite of $4.0 \mathrm{Cl}^{-} /$unit cell. Free chloride is the operation metric for heated $v$-mixing. The target value for free chloride is $0.05 \mathrm{wt} \%$. It is believed that free chloride is a measure of how well the salt has been incorporated into the cages of the zeolite. Free chloride is measured by taking a sample of saltloaded zeolite from a contacting experiment. The sample is washed with distilled water and the amount of chloride in solution is determined with an ion specific electrode. Over 40 contacting experiments have been completed with free chloride ranging from 0.01 to $2.1 \mathrm{wt} . \%$.

The HIP process is utilized to convert the salt-loaded zeolite to sodalite, and to solidify the materials into a monolith. A simple operation metric utilized to evaluate the process is the volume change in the HIP can. If the volume of the HIP can has decreased significantly, the process has consolidated the materials in the can. X-ray diffraction of the ceramic waste form is the operation metric for the HIP process to evaluate the conversion of salt-loaded zeolite to sodalite.

\section{PRODUCT SENSTTIVITY}

Because the ceramic waste form production process is under development, the sensitivity of the quality of the final product to all process operation metrics has not been evaluated, however select examples are presented. The quality of the ceramic waste form is evaluated with a multitude of techniques. An assessment is made of physical properties, microstructure, phase composition, and durability of the ceramic. Primary evaluation techniques include $\mathrm{x}$-ray diffraction (XRD), scanning electron microscopy (SEM), transmission electron microscopy (TEM), and numerous leach tests. Durability evaluations include the product consistency test (PCT), Materials Characterization Center MCC-1, vapor hydration test (VHT), flow-thru test, and pulsed-flow test. The metric of performance considered here is the PCT durability test. The performance metric is used to evaluate product sensitivity of the ceramic waste form to operation metrics.

ASTM C1285-94, the Product Consistency Test (PCT), is a solution-based test performed on virtually all samples. The conditions for this test are a duration of 7 days, a temperature of 
Table 2. Operation and Performance Metrics for Select Experiments

\begin{tabular}{|c|c|c|c|c|c|c|c|c|}
\hline \multicolumn{9}{|c|}{ Operation Metrics/Operating Parameters } \\
\hline can \# & $\begin{array}{c}\text { zeolite } \\
\text { moisture } \\
(w t . \%)\end{array}$ & $\begin{array}{c}\text { free } \\
\text { chloride } \\
\text { (wt.\%) }\end{array}$ & $\begin{array}{c}\text { volume } \\
\text { change } \\
(\%)\end{array}$ & $\begin{array}{c}\text { minor } \\
\text { nepheline }\end{array}$ & $\begin{array}{c}\text { trace } \\
\text { nepheline }\end{array}$ & $\begin{array}{c}\text { no } \\
\text { nepheline }\end{array}$ & $\begin{array}{c}\text { HIP } \\
\text { pressure } \\
(\mathrm{Pa})\end{array}$ & bake out \\
\hline 56 & 0.211 & 0.56 & 58 & 0 & 0 & 1 & 14500 & 1 \\
\hline 57 & 0.211 & 0.56 & 46.7 & 0 & 0 & 1 & 14500 & 1 \\
\hline 58 & 0.076 & 0.09 & 47.4 & 1 & 0 & 0 & 14500 & 1 \\
\hline 59 & 0.076 & 0.09 & 48.7 & 1 & 0 & 0 & 14500 & 1 \\
\hline 60 & 0.193 & 1.25 & 61.3 & 0 & 1 & 0 & 14500 & 1 \\
\hline 61 & 0.193 & 1.25 & 62.2 & 0 & 1 & 0 & 14500 & 1 \\
\hline 62 & 0.193 & 1.25 & 58.6 & 0 & 1 & 0 & 24500 & 1 \\
\hline 63 & 0.193 & 1.25 & 58.4 & 0 & 0 & 1 & 14500 & 0 \\
\hline 64 & 0.211 & 0.56 & 61.5 & 0 & 0 & 1 & 14500 & 1 \\
\hline 65 & 0.211 & 0.56 & 57.7 & 0 & 0 & 1 & 14500 & 0 \\
\hline 66 & 0.076 & 0.09 & 48.2 & 1 & 0 & 0 & 24500 & 1 \\
\hline 67 & 0.076 & 0.09 & 43.1 & 1 & 0 & 0 & 14500 & 0 \\
\hline 389 & 0.211 & 0.56 & 40.9 & 0 & 0 & 1 & 24500 & 1 \\
\hline 390 & 0.076 & 0.09 & 52.7 & 1 & 0 & 0 & 14500 & 1 \\
\hline \multicolumn{9}{|c|}{ Performance Metrics } \\
\hline can \# & $\begin{array}{l}\text { Li NRR } \\
\left(\mathrm{g} / \mathrm{m}^{2} \mathrm{~d}\right) \\
\end{array}$ & $\begin{array}{c}\text { Na NRR } \\
\left(\mathrm{g} / \mathrm{m}^{2} \mathrm{~d}\right)\end{array}$ & $\begin{array}{c}\text { Rb NRR } \\
\left(\mathrm{g} / \mathrm{m}^{2} \mathrm{~d}\right)\end{array}$ & $\begin{array}{l}\text { Cs NRR } \\
\left(\mathrm{g} / \mathrm{m}^{2} \mathrm{~d}\right) \\
\end{array}$ & $\begin{array}{l}\text { Si NRR } \\
\left(\mathrm{g} / \mathrm{m}^{2} \mathrm{~d}\right)\end{array}$ & $\begin{array}{l}\text { Al NRR } \\
\left(\mathrm{g} / \mathrm{m}^{2} \mathrm{~d}\right)\end{array}$ & $\begin{array}{c}\text { B NRR } \\
\left(\mathrm{g} / \mathrm{m}^{2} \mathrm{~d}\right)\end{array}$ & $\begin{array}{l}\text { Cl NRR } \\
\left(\mathrm{g} / \mathrm{m}^{2} \mathrm{~d}\right)\end{array}$ \\
\hline 56 & $4.60 \mathrm{E}-02$ & $1.00 \mathrm{E}-02$ & $6.90 \mathrm{E}-03$ & $5.50 \mathrm{E}-03$ & $9.50 \mathrm{E}-03$ & $1.00 \mathrm{E}-02$ & $1.60 \mathrm{E}-02$ & $2.00 \mathrm{E}-02$ \\
\hline 57 & $6.60 \mathrm{E}-02$ & $7.10 \mathrm{E}-03$ & $1.20 \mathrm{E}-02$ & \begin{tabular}{|l|}
$1.20 \mathrm{E}-02$ \\
\end{tabular} & $1.00 \mathrm{E}-02$ & $7.40 \mathrm{E}-03$ & $3.70 \mathrm{E}-02$ & $1.70 \mathrm{E}-02$ \\
\hline 58 & $4.60 \mathrm{E}-02$ & $8.20 \mathrm{E}-03$ & $4.50 \mathrm{E}-03$ & $5.20 \mathrm{E}-03$ & $7.40 \mathrm{E}-03$ & $8.30 \mathrm{E}-03$ & $7.50 \mathrm{E}-03$ & $1.50 \mathrm{E}-02$ \\
\hline 59 & $4.50 \mathrm{E}-02$ & $8.00 \mathrm{E}-03$ & $4.30 \mathrm{E}-03$ & $5.40 \mathrm{E}-03$ & $7.10 \mathrm{E}-03$ & $8.30 \mathrm{E}-03$ & $7.20 \mathrm{E}-03$ & $1.50 \mathrm{E}-02$ \\
\hline 60 & $4.80 \mathrm{E}-02$ & $8.30 \mathrm{E}-03$ & $8.10 \mathrm{E}-03$ & $6.90 \mathrm{E}-03$ & $9.50 \mathrm{E}-03$ & $9.10 \mathrm{E}-03$ & $2.00 \mathrm{E}-02$ & $1.70 \mathrm{E}-02$ \\
\hline 61 & $4.70 \mathrm{E}-02$ & $9.20 \mathrm{E}-03$ & $8.40 \mathrm{E}-03$ & $6.20 \mathrm{E}-03$ & $9.50 \mathrm{E}-03$ & $9.50 \mathrm{E}-03$ & $1.80 \mathrm{E}-02$ & $1.90 \mathrm{E}-02$ \\
\hline 62 & $4.60 \mathrm{E}-02$ & $9.70 \mathrm{E}-03$ & $8.90 \mathrm{E}-03$ & $5.80 \mathrm{E}-03$ & $9.50 \mathrm{E}-03$ & $9.40 \mathrm{E}-03$ & $2.40 \mathrm{E}-02$ & $2.10 \mathrm{E}-02$ \\
\hline 63 & $4.80 \mathrm{E}-02$ & $9.20 \mathrm{E}-03$ & $9.50 \mathrm{E}-03$ & $7.20 \mathrm{E}-03$ & $1.00 \mathrm{E}-02$ & $9.70 \mathrm{E}-03$ & $1.90 \mathrm{E}-02$ & $1.80 \mathrm{E}-02$ \\
\hline 64 & $4.40 \mathrm{E}-02$ & $1.00 \mathrm{E}-02$ & $8.30 \mathrm{E}-03$ & $5.60 \mathrm{E}-03$ & $9.60 \mathrm{E}-03$ & $9.50 \mathrm{E}-03$ & $2.40 \mathrm{E}-02$ & $2.00 \mathrm{E}-02$ \\
\hline 65 & $4.80 \mathrm{E}-02$ & $9.90 \mathrm{E}-03$ & $8.60 \mathrm{E}-03$ & $6.00 \mathrm{E}-03$ & $1.00 \mathrm{E}-02$ & $1.00 \mathrm{E}-02$ & $1.80 \mathrm{E}-02$ & $1.90 \mathrm{E}-02$ \\
\hline 66 & $4.00 \mathrm{E}-02$ & 8.80E-03 & $5.60 \mathrm{E}-03$ & $5.80 \mathrm{E}-03$ & 7.70E-03 & 8.30E-03 & $1.00 \mathrm{E}-02$ & $1.60 \mathrm{E}-02$ \\
\hline 67 & 4.30E-02 & $8.80 \mathrm{E}-03$ & $5.70 \mathrm{E}-03$ & $6.10 \mathrm{E}-03$ & $7.60 \mathrm{E}-03$ & $8.20 \mathrm{E}-03$ & $1.10 \mathrm{E}-02$ & $1.90 \mathrm{E}-02$ \\
\hline 389 & $4.20 \mathrm{E}-02$ & 9.90E-03 & $9.30 \mathrm{E}-03$ & $7.40 \mathrm{E}-03$ & $9.20 \mathrm{E}-03$ & 9.20E-03 & $1.90 \mathrm{E}-02$ & $2.00 \mathrm{E}-02$ \\
\hline 390 & $4.00 \mathrm{E}-02$ & 8.30E-03 & $5.40 \mathrm{E}-03$ & $6.10 \mathrm{E}-03$ & $7.50 \mathrm{E}-03$ & $8.30 \mathrm{E}-03$ & $9.40 \mathrm{E}-03$ & $1.60 \mathrm{E}-02$ \\
\hline
\end{tabular}

$90^{\circ} \mathrm{C}$, and a sample surface area to volume leachant ratio of $2000 \mathrm{~m}^{-1}$. The test material is in the -100 to +200 mesh size fraction. Normalized release rates (NRR) for waste form components are determined from analysis of the leach test solution. Table 2 provides the NRR for select durability experiments where operation metrics had varied during production of the ceramic waste form. The information provided in Table 2 was obtained for a very cursory examination of the impact of operation metric variability on the performance of the final product. As mentioned previously, a much more detailed evaluation of the sensitivity of the final product performance to the operation metrics is currently being completed. A numerical value of 0 or 1 is utilized in some columns to indicate a positive response to the column heading. For example, 
a numerical value of 1 for can 56 under the bake-out heading means that bake-out was completed for that can. A numerical value of 1 for can 58 under the minor nepheline column means that a minor amount of nepheline was observed with $\mathrm{x}$-ray diffraction.

First and foremost, the NRR's for the waste form compare very favorably with other high-level waste forms. A cursory examination of the data reveals little sensitivity of the final product to the operation metrics. The aforementioned statement is valid only for the range of operation metrics considered and the performance test used to evaluate the sensitivity. A more sensitive performance test and/or a larger range for the operation metrics may reveal a greater amount of sensitivity. Although the data is too sparse to determine absolute sensitivities from a statistical analysis of the information, trends can be resolved. A correlation analysis of the information presented in Table 2 reveals no sensitivity of the ceramic performance to the HIP operation metric of volume change and to the bake-out operation. The analysis also suggests that the durability of the ceramic waste form is slightly improved with the presence of minor amounts of nepheline. However, the slight improvement cannot be solely attributed to the presence of nepheline. Experiments 58, 59, 66, 67, and 390 were completed with salt-loaded zeolite that had been produced from a granular zeolite. The remainder of the experiments shown in Table 2 utilized zeolite that was initially in a powdered form. Aside from the difference in mean particle size, the main difference between the powdered and granular zeolite is the presence of a clay binder in the granular zeolite. It appears that the clay binder promotes the formation of minor amounts of nepheline in the final product. The durability of the ceramic appears to decrease slightly as the amount of moisture present in the dried zeolite and the amount of free chloride present in the salt-loaded zeolite increase. This observation is consistent with the belief that minimization of moisture in the zeolite and free chloride in the salt-loaded zeolite would be beneficial to waste form performance. In the more advanced evaluation that is underway, larger ranges of the operation metrics are being evaluated as well as some HIP process parameters that were not evaluated for this study.

\section{CONCLUSIONS}

The development of a ceramic waste form for the immobilization of radionuclides from an electrometallurgical treatment process was presented. A brief discussion of the relevant processes and their operation was given. Metrics have been defined to represent the success or completion of a given operation. A cursory evaluation was presented for the sensitivity of product performance metrics to operation metrics. For the range of operation metrics and the specific performance metrics considered, very little sensitivity of the process was observed. The process appears to be quite robust. Trends where the durability of the product may decrease slightly as the moisture of the dried zeolite increases and the free chloride in the salt-loaded zeolite increases were developed from a correlation analysis. However, due to the sparseness of the data no definitive statements can be made at this time. A more detailed sensitivity study is currently underway that will include a broader range of operation metrics and process parameters.

\section{ACKNOWLEDGEMENTS}

This work was supported by the U.S. Department of Energy, Nuclear Energy Research and Development Program, under Contract W-31-109-Eng-38. 


\section{REFERENCES}

1. U.S. Department of Energy, 'Draft Environmental Assessment-Electrometallurgical Treatment Research Demonstration Project in the Fuel Conditioning Facility at Argonne National Laboratory-West,' $D O E / E A-1148$, Department of Energy, Washington, DC, (1996).

2. Technical Strategy for the Management of INEEL Spent Nuclear Fuel, Volume I, A report of the INEEL Spent Nuclear Fuel Task Team, prepared for DOE Office of Spent Fuel Management, (1997).

3. K.M. Goff, M.F. Simpson, S.G. Johnson, K.J. Bateman, T.J. Battisti, and S.M. Frank, in Proceedings of the Third Topical Meeting on DOE Spent Nuclear Fuel and Fissile Materials Management, (American Nuclear Society, Illinois, 1998).

4. S.K. MacLeod, Analytical Chemistry 63 (10), 557-566 (1991). 